\title{
The Effectiveness of Sociodrama to Improve Students' Anger Management Skills
}

\author{
Iyum Tsamratul Ainil Alawiyah ${ }^{1}$, Agus Taufiq, Anne Hafina \\ Universitas Pendidikan Indonesia, Indonesia \\ @iyumalawiyah25@gmail.com ${ }^{1}$
}

\begin{abstract}
Article Information:
Received January 6, 2019

Revised February 21, 2019

Accepted April 1, 2019
\end{abstract}

Keywords: anger management; sociodrama; psychoeducational group

\begin{abstract}
The school students still show aggressive behavior such as shouting, swearing and glaring when offended, mocking, kicking and fighting, all of these are because of the uncontrolled anger. The purpose of this study was to examine the effectiveness of sociodrama within psychoeducational group to improve anger management skills for class XI students of State Madrasah Aliyah 3 Majalengka. A quasi-experimental method with 30 participants of class XI State Madrasah Aliyah 3 Majalengka were administered. The random sampling technique was used in this study. The results of 40 items test for anger management skills scale obtained 30 items are valid $(\alpha=0.90)$. Data analysis to determine the effectiveness of the sociodrama to improve anger management skills through Wilcoxon test. The results showed the skills to manage anger of students generally in the medium category, it means that students already have the skills to manage anger but it is not yet been consistent, therefore, sometimes students showed aggressive behavior and sociodrama technique within psychoeducational group is effective to improve students anger management skills.
\end{abstract}

\section{INTRODUCTION}

Adolescence is transition period between childhood to adulthood that signed by growth and development biological and psychological. Biological is signed by the growth and development of primary sex and secondary sex, while psychological signed by unstable or erratic attitudes, feelings, desires, and emotions (Santrock, 2014). Furthermore, Santrock (2014) suggests that adolescence is often referred to as a period full of storms and stress. The period in which emotional tension rises as a result of physical changes (Hurlock, 1997).

Sanderse (2015) opinion that is in line with the opinion above that at the beginning of adolescence individuals are often unstable and impatient, caused to lack of self-control needed to become a mature person. Changes that occur in adolescence as well as changes in their environment can often lead to emotional disturbances and behavioral disorders as a result of the pressures experienced by adolescence. Hurlock (1997) also explains that adolescence mostly experience instability over time as a consequence and attempt to adjust to new behaviors and new social expectations. Hurlock's opinion was reinforced by the results of a research in Chicago by Larson in 1999 that adolescence generally experience mood swings, where adolescence need only 45 minutes to change from a mood of extraordinary pleasure to extraordinary sadness, while adults need several hours for the same thing (Larson \& Lampman-Petraitis, 1989).

Important developmental tasks in adolescence are accepting more mature relationships with peers of any sex, achieving social roles as men and women, achieve emotional

$\begin{array}{ll}\text { How to cite: } & \text { Alawiyah, I. T. A., Taufiq, A., \& Hafina, A. (2019). The Effectiveness of Sociodrama to Improve Students' } \\ & \text { Anger Management Skills. Is/amic Guidance and Counseling Journal, 2(2). 56-65. } \\ & \text { https://doi.org/10.25217/igcj.v2i2.397 } \\ \text { E-ISSN: } & \text { 2614-1566 } \\ \text { Published by: } & \text { Institut Agama Islam Ma'arif NU (IAIMNU) Metro Lampung } \\ \text { Available online: } & \text { https://journal.iaimnumetrolampung.ac.id/index.php/igcj }\end{array}$


independence from parents and other adults, preparing independence, obtain a set of values and an ethical system as a guide in behaving (Manning, 2002). Development tasks that must be completed by adolescence are generally demands from the surrounding environment as an effort to adjust.

Environmental demands cause in pressures that cause in increasing emotional. motion is needed to help humans adapt to the environment more easily. Swasti \& Martani (2013) suggest that humans need to learn how to control themselves, control and express their emotions to manage behavior in order to adapt well. In general, there are two kinds of emotions in humans namely positive emotions and negative emotions. Joy, love, emotion are some forms of positive emotions, while depression, disappointment, sadness, anger and many more are forms of negative emotions (Safira \& Saputra, 2009). In life, there are various factors that can cause anger in individuals. According to Bhave \& Saini (2009), the thing that most often causes anger is when someone faces an inappropriate situation, feeling frustrated or disappointed and when having a desire that is not fulfilled.

The phenomenon of lack of emotional management skills occurs also in State Madrasah Aliyah 3 Majalengka and based on preliminary studies that have been carried out through interviews with guidance and counseling teachers of State Madrasah Aliyah 3 Majalengka, the result is that in State Madrasah Aliyah 3 Majalengka there are still many students who cannot control their emotions, especially anger. Like what happened with two female students who fighting at school and were seen by other students. There are also students who fighting on social media because they tease each other and status war.

Other phenomena in school, based on the observations of the authors also showed that in the class there were still some students who still showed aggressive attitudes due to perceived angry, such as shouting when talking, making fun, swearing and glaring when offended and not receiving words his friend, cornered each other, talked too much, give nicknames, mock, kick and when they joke together and suddenly turn into a quarell and even a fight. Likewise, in overcoming emotional feelings students express it by indulging in excessive anger, such as: loud, yelling, hitting, crying, bullying and fighting.

The phenomena mentioned above are strengthened by the statement of Barlow et al., (2017) that individuals who are unable to control emotions are easily frustrated, anxious and resolve problems in emotional ways. Adolescence have not been able to control emotions more precisely and express emotions in ways that are accepted by society (Santrock, 2014). Various behaviors of inability to manage emotions are a picture of uncontrolled emotions, and reflect a heightened emotional imbalance, even though emotions play an important role in individual behavior (Goleman, 2006). Based on the previous statement, needed an ability to manage emotions. The ability to manage emotions is the highest component of emotional intelligence. Goleman stated that emotional intelligence is an ability that someone have in motivating themselves, endurance in the face of failure, the ability to control emotions, and the ability to regulate the state of the soul.

Adolescence who are better able to manage emotions, they will be better able to cope with any discomfort experienced (Fernández-Berrocal \& Aranda, 2017). Therefore, adolescence able to manage the emotions of anger and are able to express emotions of anger in ways that are more acceptable then it is necessary to develop a method or technique of guidance and counseling that is appropriate needs of students in school, specifically techniques for improving students' anger management skills. One of the technique in guidance and counseling to improve students' anger management skills is sociodrama.

Sociodrama techniques are usually used as a formulation for social problems. This is in accordance with the statements of Kellermann (1998) and Carter (2009) which state that sociodrama is usually used to deal with social problems. Furthermore, Kellermann (2007) said that sociodrama is an experiential group as a whole procedere for social exploration and 
intergroup conflict transformation and sociodrama was develop as a deep action method for dealing with intergroup relation and collective ideologies.

Anger is a form of emotion and is included in negative emotions. Anger is an emotional phenomenon, an emotional reaction, and has the characteristics of sympathetic nerve activity, as stated by three following experts. Psychologically, anger is an emotional phenomenon (Wetrimudrison, 2005). In more complete version, Chaplin (1997) in the Dictionary of Psychology explains that anger is an acute emotional reaction that arises because of a number of stimulating situations, including threats, outward aggression, self-restraint, verbal attacks, disappointment, frustration, and characterized by strong reactions to the autonomic nervous system, especially by reactions to outward attacks, whether somatic or physical as well as verbal or verbal. Kop et al., (2011) suggest anger is an emotion that has the characteristics of a high sympathetic nervous system activity. The specific nature of the individual response are important factors in the autonomic nervous system responses to emotional states (Kreibig, 2010).

The ability to manage emotions is very important because when a child or adolescence can regulate his emotions therefore he will be more productive than children who lack emotional skills. People who are emotionally intelligent or able to manage their emotions have been described as people who are able to adjust well, warmly, sincerely, persistently and optimistically. This is believed to include social and cognitive functions as related to emotional expression (Schutte et al., 1998).

According to Goleman (2006) that managing emotions is to deal with feelings so that feelings can be expressed correctly which depend on self-awareness that is recognizing feelings when those feelings occur. Furthermore, Goleman argue that managing emotions is the ability to regulate feelings, calm down, escape from anxiety, moodiness or offense, in order to balance emotions (balance between feelings and environment).

In line with Goleman, according to Gentry (2011) anger management is an individual's ability to control the anger possessed and gave a response to it in a way that can be accepted by the surrounding environment. From this opinion we can draw a red thread that controlling anger is also called or equal to managing anger.

Anger has a very important role in the emergence of depression and is one of the factors that cause suicide risk for adolescence (Cautin, Overholser, \& Goetz, 2001). The inability to manage anger can have a negative impact on both yourself and others. The negative impact caused by anger according to Bhave \& Saini (2009) is the existence of hostility, hatred, bitterness and hate, damaging aggression, verbal aggression, physical aggression, persecution and murder. In order for the negative impact of anger of students in schools to be overcome or minimized, there is a need for preventive or curative treatment that is guidance and counseling services. One of the services in guidance and counseling that is suitable for the ability to manage anger is sociodrama.

The sociodrama technique used in the research will conducted within psychoeducational group, aimed to develop students' emotional management skills. In a recent study, Sholikhah (2018) had offered psychodrama to improve emotional stability, but authors will use sociodrama instead. Yusuf \& Nurihsan (2006) suggested psychoeducational group as the guidance intended to respond to the needs and interests of students. The topics provided in this service are common problems and not confidential. Sosiodrama in guidance and counseling can be used as a technique to help students solve their social problems or develop social skills. Sociodrama is one of technique that can be used to help counselee in expressing their feelings. The sociodrama technique that will be discussed in this research is about the understanding of sociodrama, the purpose of sociodrama, and the basic components of sociodrama. 
According to Marineau (2013) sociodrama is science and art, focusing on the roots and meanings of intergroup relations and conflict, and ways to change them, if needed. Sociodrama includes prevention and treatment. A more complete definition was put forward by Blatner (2009) based on the assumption that certain groups and are organized are influenced by the social role and cultural level of a particular society. Sociodrama as the basis for developing psychodrama methods, that is a method or technique based on and aimed to catharsis social conflict in general which occurs and develops in group interactions of a personal and group nature, by playing a role using the theater approach (drama).

Several studies have stated that sociodrama techniques have a positive relationship with emotional management skills so that the sociodrama technique is effective to improve the emotional management skills of high school students who have been tested theoretically through expert testing and have been practically tested through field trials (Rahayu, 2009). Furthermore, Sociodrama to overcome students' verbal aggression (Sari, Lasan, \& Sari, 2017; Winarlin, Lasan, \& Widada, 2016), improve assertive behavior (Fidyah, Rosra, \& Andriyanto, 2018), and foster cultural humility (Loue, 2018). But these research did not focus on anger management skills improvement and did not reveal based on student background and the factors that influence the ability to manage anger. Therefore, this research was conducted to examine and fill the gaps that have not been discussed by these studies.

In general, the purpose of sociodrama is to help students solve problems that occur in their social environment through role playing techniques. According to Eckloff (2006) sociodrama aims to provide opportunities for members to deepen their sensitivity and reason into social problems so that they can 1) increase social understanding; 2) increase knowledge about the participation of the counselee itself, and 3) increase emotional relationships or catalyze the role of many people by expressing the counselee's feelings about someone or someone else.

Therefore, the purpose of this study is to determine the effectiveness of sociodrama in imrove students' anger management skills. These are the hypotheses of the study there is no difference in the average pre-test and post-test data, meaning that there is no significant difference after the intervention if $\operatorname{sig} \geq 0.05$ (H0), and there are differences in the average pre-test and post-test data, meaning that there are significant differences after the intervention if sig $<0.05(\mathrm{H} 1)$.

\section{METHODS}

The research method used is quasi-experimental research. The research design used was one group of subjects (one group pretest and posttest design), which was a research design that only included one group which was given pre and post-test (Subana, 2005).

The sampling technique in this study is a random sample, namely the technique of determining the sample by mixing the subjects in the population so that all subjects are considered the same (Arikunto, 2010). Sampling is based on Surahmad's opinion stating that "If the population is less than 1000 people, then sampling is at least 50\% of the entire population. If the population size is equal to or more than 100 , the sample size is expected to be at least $15 \%$ of the population size (Riduwan, 2006). The population in the study was 150 people. Then the sample is $15 \%$ of 150 people, as many as 23 people, but rounded up to 30 people.

The research instrument used was a questionnaire to reveal the ability to manage anger. The purpose of using the questionnaire is to describe the ability to manage anger in class XI State Madrasah Aliyah 3 Majalengka Academic Year 2017/2018. The grid and instruments used contain statements about emotional management skills developed from aspects 1) recognize anger, 2) control anger, 3) relieve anger, and 4) express assertive anger emotionally. 
The results of validity test 40 items for anger management instrument, obtained 10 items are not valid, so that the total valid question items are 30 items (The following are some statements on the instrument's ability to manage anger "Usually when I'm upset, I hit whatever objects are near me.", "When I am angry, I will reply to someone who hurt me without thinking about the consequences.", "I feel unsatisfied, if I have not cursed people who make me angry.", "When I am angry, I prefer to harbor my anger in my heart.", "When I am angry I try to calm my feelings by regulating breathing.". Based on the results of the calculation of the emotions management skills instrument obtained reliability 0.90 which means that the degree of reliability of the instrument used is high, meaning that this instrument is able to produce scores on items with consistent and feasible to be used in research as a data collection tool. The hypotheses were tested with Wilcoxon assisted by SPSS 25.

\section{RESULTS AND DISCUSSION}

The results of the recapitulation of the categorization of the level of ability to manage anger of class XI students of State Madrasah Aliyah 3 Majalengka in the 2017/2018 Academic Year which are used as research samples displayed in Table 1.

\begin{tabular}{ccc}
\hline Categorization & Total of students & Percentage \\
\hline High & 8 people & $26,7 \%$ \\
Low & 15 people & $50 \%$ \\
Medium & 7 people & $23,3 \%$ \\
Total & 30 people & $100 \%$ \\
\hline
\end{tabular}

Table 1. An overview of the students' anger management skills

Based on the Table 1, it is known that out of 30 students there are 8 students belonging to students who have the ability to manage anger with a high category $(26.7 \%)$, there are 15 students who have the ability to manage anger in the medium category (50\%) and 7 students who have the ability to manage anger in the low category (23.3\%). This shows that in general the ability to manage anger in class XI State Madrasah Aliyah 3 Majalengka in the academic year 2017/2018 is in the medium category meaning that students already have the ability to manage anger but the ability to manage anger is not always there or is not consistent so sometimes it still appears behaviors such as screaming, mocking, swearing, kicking and fights.

\begin{tabular}{cccc}
\hline Aspect & Categorization & Total of student & Percentage \\
\hline Recognize anger & High & 9 & $30 \%$ \\
& Medium & 14 & $46,7 \%$ \\
\multirow{3}{*}{ Control \& relieve anger } & Low & 7 & $23,3 \%$ \\
& High & 8 & $26,7 \%$ \\
& Medium & 18 & $60 \%$ \\
Express assertive anger & Low & 4 & $13,3 \%$ \\
& High & 3 & $10 \%$ \\
& Medium & 14 & $46,7 \%$ \\
& Low & 13 & $43,3 \%$ \\
\hline
\end{tabular}

Table 2 . An overview of the ability to manage students' anger based on each aspect

The ability to manage anger in this study was measured based on four aspects of the ability to manage students' anger namely, recognizing anger, controlling anger, relieving anger, and expressing assertive anger. The description of the ability to manage anger in class 
XI State Madrasah Aliyah 3 Majalengka Academic Year 2017/2018 based on each aspect can be seen in the Table 2 .

Based on the Table 2, it is known that the ability to manage anger in class XI State Madrasah Aliyah 3 Majalengka Academic Year 2017/2018 based on aspects that measure the majority is included in the medium category means that students already have the ability to recognize anger, control and relieve anger, and express anger assertively. But this ability is not always present or not consistent. Whereas students who are in the low category means that students do not yet have the ability to recognize anger, control and relieve anger, and express assertive anger. And students who have the ability to manage their emotions highly means that students already have the ability to recognize anger, control and relieve anger, and express anger assertively.

The Table 3. shows that there are differences between the results of the pre-test $(\mathrm{M}=$ $16.70, \mathrm{SD}=6.08)$, post-test $(\mathrm{M}=22.70, \mathrm{SD}=3.96)$, Wilcoxon value $\mathrm{Z}=-2.619$, and probability $\mathrm{p}=0.008<0.05$. Therefore, the $\mathrm{H} 0$ is rejected and $\mathrm{H} 1$ is accepted, meaning that the student's ability to manage anger at the time of the post-test is greater than the score at the pre-test. In other words there are significant differences in students' anger management skills between before and after the implementation of sociodrama techniques. Thus, the sociodrama is effective to improve students' anger management skills.

\begin{tabular}{ccc}
\hline Measurement & & Experiment $(\mathbf{N}=\mathbf{3 0})$ \\
\hline Pretest & M & 16.70 \\
& SD & 6.08 \\
Posttest & M & 22.70 \\
& SD & 3.96 \\
& Z & -2.619 \\
& P & $0.008(<0.05)$ \\
\hline
\end{tabular}

Table 3. Mean, standard deviation, and Wilcoxon test results

The ability to manage anger is very important for students, because when students are not able to manage their emotions, they will easily be frustrated, anxious and resolve problems emotionally (Hubbard, 2016). Research conducted by Mayer, Salovey, \& Caruso (2004) revealed that a person with high emotional management ability has a lower tendency towards violent and bullying behavior and is able to adapt.

Efforts to improve the ability to manage anger of students by conducting psychoeducational group services with sociodrama techniques. Psychoeducational group services with sociodrama techniques in improving the ability to manage anger of class XI students of State Madrasah Aliyah 3 Majalengka Academic Year 2017/2018 are arranged in the form of plans for psychoeducational and counseling group.

The results of the effectiveness test using the sociodrama technique in improving the ability to manage anger of class XI students of State Madrasah Aliyah 3 Majalengka in the Academic Year 2017/2018 using two different test results. the average shows the use of sociodrama techniques effective in increasing the ability to manage anger. The use of sociodramas is said to be effective because it works to improve the ability to manage students' anger both in whole and in every aspect, namely recognizing anger, controlling anger, relieve anger, and expressing anger assertively.

The results of this study are in accordance with the objectives of the study and in accordance with previous studies, because the sociodrama technique has been proven to be effective in increasing the ability to manage anger. Sociodrama techniques are suitable for improving the ability to manage anger because sociodrama techniques are techniques used to express various types of feelings that suppress (negative feelings) through an atmosphere that 
is designed in such a way that the client can freely express himself orally, in writing or through dramatic movements (Surya, 1985).

The improvement of students' anger management skills built based on the awareness of his or her own feel. It is supported by Loue (2018), sociodrama build an awareness of how individuals may feel alienated and dislocated, help to develop empathy, and provide an opportunity for individuals to explore possible responses to a variety of situations.

The anger turned in to assertive behavior which more constructive. The assertive behavior will lead one's to a better judgement and act appropriately, as Fidyah, Rosra, \& Andriyanto (2018) had proved the sociodrama will improve students' assertive behavior.

The authors have several limitations in the implementation of the following. Research on the effectiveness of sociodrama techniques in improving the ability to manage students' anger is not independent of obstacles and limitations. Time is one of the obstacles in implementing interventions. The implementation of sociodrama can only be carried out during break times or when subject teachers are not included in the class and only give assignments so the counselee feels tired because the break times is used for sociodrama activities.

Research on the ability to manage anger is not yet comprehensive because it only examines the ability to manage anger in class XI of State Madrasah Aliyah 3 Majalengka not for all students at every level. The research method used is a pre - experimental method with design one group pre test and post test so that nobody student becomes a comparison class or control class, so the effectiveness of sosiodrama techniques is less visible

\section{CONCLUSIONS}

Based on the results of research the ability to manage anger of students generally is in the medium category, it means that students already have the ability to manage anger but the ability to manage anger is not been consistent so that sometimes students showed aggressive behavior. Sociodrama techniques within psychoeducational group is effective to improve emotional management skills. The results showed that several changes in the level of skills to manage anger among participated students after posttest. Based on these results the skills to manage anger of participated students had a significant improvement. It can be assumed that psychoeducational group services through sociodrama techniques have proven effective for improving emotional management skills.

Guidance and counseling teachers need to be aware that increasing emotional management needs to be given to all students, this will be useful for students in undergoing the process of learning activities in school and will be useful also for students in carrying out their roles as family members and the community.

\section{ACKNOWLEDGMENTS}

The author expresses their sincere appreciation to Dr. Nurhudaya, M.Pd. as head of the psychology department of education and guidance who has given motivation to authors to immediately complete this research, and Dra. Hj. Euis Damayanti, M.P. Kim. who has given permission to carry out research in State Madrasah Aliyah 3 Majalengka.

\section{AUTHOR CONTRIBUTION STATEMENTS}

ITA conducted a preliminary study to obtained preliminary data, then formulated a draft of research topic for further investigation, and discussed it with AH and AT. Research begins by looking for theories that are in accordance with the topic of research, then making a research instrument. The instrument was then assessed by two supervisors, after the instrument received input from the supervisor then it was revised, the instrument was tested for its validity and reliability. ITA made a procedure for implementing psychoeducational 
group by using sociodrama techniques to improve students' ability to manage anger and write research reports. AH and AT evaluated and re-checked the initial data, the implementation of sociodrama, and the results after careful intervention. Thus, the technique used to improve the ability to manage emotions in accordance with the theory and answer research questions.

\section{REFERENCES}

Arikunto, S. (2010). Prosedur Penelitian Suatu Pendekatan Praktek. Jakarta: PT. Rineka Cipta. Retrieved from Google Scholar

Barlow, D. H., Farchione, T. J., Sauer-Zavala, S., Latin, H. M., Ellard, K. K., Bullis, J. R., Cassiello-Robbins, C. (2017). Unified Protocol for Transdiagnostic Treatment of Emotional Disorders: Therapist Guide. Oxford University Press. Retrieved from Google Scholar

Bhave, S. Y., \& Saini, S. (2009). Anger Management. SAGE Publication India. Retrieved from Google Scholar

Blatner, A. (2009). Bases del psicodrama. Editorial Pax Mexico. Retrieved from Google Scholar

Carter, P. D. (2009). The Drama Is Always Right in Front of You: Sociodrama for the Development of Social Insight and Action. Qualitative Inquiry, 15(9), 1480-1497. https://doi.org/10.1177/1077800409343062

Cautin, R. L., Overholser, J. C., \& Goetz, P. (2001). Assessment of mode of anger expression in adolescent psychiatric inpatients. Adolescence, 36(141), 163-170. Retrieved from Google Scholar

Chaplin, J. P. (1997). Kamus Lengkap Psikologi,(Terjemahan dari Dr. Kartini Kartono). Jakarta: PT. Raja Grafindo Persada. Retrieved from Google Scholar

Eckloff, M. (2006). Using Sociodrama to Improve Communication and Understanding. Et Cetera, 63(3), 259. Retrieved from Google Scholar

Fernández-Berrocal, P., \& Aranda, D. R. (2017). La Inteligencia emocional en la Educación. Electronic Journal of Research in Education Psychology, 6(15), 421-436. https://doi.org/10.25115/ejrep.v6i15.1289

Fidyah, F., Rosra, M., \& Andriyanto, R. E. (2018). Penggunaan Konseling Kelompok Teknik Sosiodrama Untuk Meningkatkan Perilaku Asertif. ALIBKIN (Jurnal Bimbingan Konseling), 6(3). Retrieved from Google Scholar

Gentry, W. D. (2011). Anger Management For Dummies. John Wiley \& Sons. Retrieved from Google Scholar

Goleman, D. (2006). Emotional Intelligence. Bantam Books. Retrieved from Google Scholar

Hubbard, P. (2016). The geographies of 'going out': Emotion and embodiment in the evening economy. In Emotional geographies (pp. 131-148). Retrieved from https://doi.org/10.4324/9781315579245

Hurlock, E. B. (1997). Psikologi Perkembangan Suatu pendekatan rentang kehidupan (Edisi Kelima). Erlangga. Retrieved from Google Scholar

Kellermann, P. F. (1998). Sociodrama. Group Analysis, 31(2), 179-195. https://doi.org/10.1177/0533316498312005 
Kellermann, P. F. (2007). Sociodrama and Collective Trauma. Jessica Kingsley Publisher. Retrieved from Google Scholar

Kop, W. J., Synowski, S. J., Newell, M. E., Schmidt, L. A., Waldstein, S. R., \& Fox, N. A. (2011). Autonomic nervous system reactivity to positive and negative mood induction: The role of acute psychological responses and frontal electrocortical activity. Biological Psychology, 86(3), 230-238. https://doi.org/10.1016/j.biopsycho.2010.12.003

Kreibig, S. D. (2010). Autonomic nervous system activity in emotion: A review. Biological Psychology, 84(3), 394-421. https://doi.org/10.1016/j.biopsycho.2010.03.010

Larson, R., \& Lampman-Petraitis, C. (1989). Daily Emotional States as Reported by Children and Adolescents. Child Development, 60(5), 1250-1260. https://doi.org/10.2307/1130798

Loue, S. (2018). Using Sociodrama to Foster Cultural Humility among Faculty and Students in the Academic Medical Center. Revista Românească Pentru Educaţie Multidimensională, 10(2), 45-57. Retrieved from Google Scholar

Manning, M. L. (2002). Havighurst's Developmental Tasks, Young Adolescents, and Diversity. The Clearing House: A Journal of Educational Strategies, Issues and Ideas, 76(2), 75-78. https://doi.org/10.1080/00098650209604953

Marineau, R. F. (2013). The Foundations of Sociodrama: Reflecting on Our Past and Looking at the Future. The Journal of Psychodrama, Sociometry, and Group Psychotherapy, 61(1), 17-27. https://doi.org/10.12926/0731-1273-61.1.17

Mayer, J. D., Salovey, P., \& Caruso, D. R. (2004). Emotional Intelligence: Theory, Findings, and Implications. Psychological Inquiry, 15(3), 197-215. https://doi.org/10.1207/s15327965pli1503_02

Rahayu, S. (2009). Pengembangan Model Sosiodrama untuk Meningkatkan Keterampilan Pengelolaan Emosi Siswa SMA (Universitas Negeri Malang). Retrieved from Google Scholar

Riduwan, M. B. A. (2006). Belajar Mudah Penelitian untuk Guru-Karyawan dan Peneliti Pemula. Bandung: Alfabeta. Retrieved from Google Scholar

Safira, T., \& Saputra, N. E. (2009). Manajemen Emosi: Sebuah Panduan Cerdas Bagaimana Mengelola Emosi Positif dalam Hidup Anda. Jakarta: PT. Bumi Aksara. Retrieved from Google Scholar

Sanderse, W. (2015). An Aristotelian Model of Moral Development. Journal of Philosophy of Education, 49(3), 382-398. https://doi.org/10.1111/1467-9752.12109

Santrock, J. W. (2014). Adolescence (15th ed.). New York: Mc. Graw Hiil Companies. Retrieved from Google Scholar

Sari, V. A., Lasan, B. B., \& Sari, E. K. W. (2017). Keefektifan Teknik Sosiodrama Untuk Mengurangi Perilaku Agresif Verbal Siswa Kelas VII di SMP Negeri 5 Kepanjen. JKI (Jurnal Konseling Indonesia), 2(2), 63-67. https://doi.org/10.21067/jki.v2i2.1942

Schutte, N. S., Malouff, J. M., Hall, L. E., Haggerty, D. J., Cooper, J. T., Golden, C. J., \& Dornheim, L. (1998). Development and validation of a measure of emotional intelligence. Personality and Individual Differences, 25(2), 167-177. https://doi.org/10.1016/S0191-8869(98)00001-4 
Sholikhah, L. D. (2018). Psychodrama Based on Al-Qur'an and Hadith to Improve Students' Emotional Stability. Islamic Guidance and Counseling Journal, 1(1), 1-10. https://doi.org/10.25217/igcj.v1i1.188

Subana, M. (2005). Dasar-dasar Penelitian Ilmiah. Bandung: Pustaka Setia. Retrieved from Google Scholar

Surya, M. (1985). Psikologi pendidikan. Bandung: Fakultas Ilamu Pendidikan, IKIP Bandung. Retrieved from Google Scholar

Swasti, I. K., \& Martani, W. (2013). Menurunkan Kecemasan Sosial melalui Pemaknaan Kisah Hidup. Jurnal Psikologi, 40(1), 39-58. Retrieved from Google Scholar

Wetrimudrison, W. (2005). Seni Pengendalian Marah dan Menghadapi Orang Pemarah. Bandung: Alfabeta. Retrieved from Google Scholar

Winarlin, R., Lasan, B. B., \& Widada, W. (2016). Efektivitas Teknik Sosiodrama Melalui Bimbingan Kelompok untuk Mengurangi Perilaku Agresif Verbal Siswa SMP. Jurnal Kajian Bimbingan Dan Konseling, 1(2), 68-73. http://dx.doi.org/10.17977/um001v1i22016p068

Yusuf, S., \& Nurihsan, A. J. (2006). Landasan Bimbingan \& Konseling. Bandung: Program Pascasarjana Universitas Pendidikan Indonesia dengan PT Remaja Rosdakarya. Retrieved from Google Scholar

Copyright Holder :

(C) Alawiyah, I. T. A., Taufiq, A., \& Hafina, A. (2019)

First Publication Right :

(C) Islamic Guidance and Counseling Journal

This article is under:

(ㄱ)(1) 